\title{
EFEKTIFITAS SEFT (SPIRITUAL EMOTIONAL FREEDOM TECHNIQUE) TERHADAP SINDROM KETERGANTUNGAN OBAT PADA LANSIA
}

\author{
Ayu Imasria Wahyuliarmy \\ be_aims@yahoo.co.id \\ Program Studi Tasawuf Psikoterapi \\ Institut Agama Islam Negeri (IAIN) Tulungagung
}

\begin{abstract}
Abstrak - Fase perkembangan terakhir pada lansia dapat digambarkan sebagai fase penurunan mental dan fisik. Lansia beresiko tinggi mengalami penyakit-penyakit kronis yang dipersepsi lansia sebagai penyakit yang tidak dapat disembuhkan, diobati, dan mempercepat kematian di usia tua, sehingga menimbulkan stres mental yang berkepanjangan, bahwa resiko mengalami depresi. Kecemasan lansia terhadap kematian, mendorong lansia mencoba berbagai cara menghidari kematian dini dengan melakukan pengobatan-pengobatan secara intensif dengan mengkonsumsi obat-obat untuk mencegah kekambuhan, menghilangkan rasa sakit, dan menghindari komplikasi, hingga menyebabkan ketergantungan pada obat obat tersebut. Studi ini bertujuan untuk mengetahui efektifitas SEFT (Spiritual Emotional Freedom Technique) pada lansia yang mengalami syndrome ketergantungan obat. Studi ini merupakan penelitian studi kasus instrumental, dengan sampel seorang lansia berusia 63 tahun yang memiliki perilaku adiksi pada obat obatan berjenis antibiotik yang dapat menghilangkan rasa nyeri, analgesik yang dapat menghilangkan rasa sakit pada keluhan keluhan fisik yang dirasakan subjek, antihistamin yang memiliki efek samping mengantuk. Hasil penelitian ini menunjukkan bahwa intervensi SEFT (Spiritual Emotional Freedom Technique) dapat mengurangi perilaku ketergantungan obat lansia yang mengalami kecemasan dan stres psikologis. SEFT menunjukkan efektif mengurangi keluhan-keluhan fisik dan psikologis secara bermakna, sehingga diikuti adanya perilaku mengurangi ketergantungan mengkonsumsi obat obatan penghilang sakit dan nyeri.
\end{abstract}

Kata Kunci: SEFT, Sindrom Ketergantungan Obat, Spiritual Emotional Freedom Technique

PSIKOISLAMIKA. Jurnal Psikologi Islam (JPI) copyright @ 2016 Pusat Penelitian dan Layanan Psikologi. Volume 13. Nomor 1, Tahun 2016

\section{PENDAHULUAN}

Masa dewasa akhir atau masa lansia, merupakan fase perkembangan terakhir yang digambarkan sebagai masa penurunan mental dan fisik yang tidak bisa dihindari. Salah satu permasalahan yang sering dihadapi adalah masalah kesehatan. Kesehatan yang buruk adalah konsekuensi yang tidak bisa dihindari dari penuaan. Kebanyakan lansia memiliki tingkat kesehatan yang secara umum cukup baik pada fase dewasa awal dan tengah. Sekitar 73 persen berusia 65 tahun ke atas meganggap diri mereka dalam kesehatan yang baik dan sempurna. Namun, pada lansia dengan resiko tinggi gangguan kesehatan, menunjukkan mengalami kondisi kronis penyakit jantung, kanker, stroke, penyakit pernafasan bawah. Di seluruh dunia, pada usia 60 tahun ke atas, penyakit tersebut merupakan penyebab kematian tertinggi pada lansia (Papalia dkk: 2009)

Faktor resiko tinggi lansia yang mengalami penyakit-penyakit kronis tersebut, dipersepsi lansia sebagai salah satu penyebab kematian. Kesalahan mempersepsi terhadap penyakit penyakit yang 
dialami lansia, seperti: tidak dapat disembuhkan, diobati, dan mempercepat kematian di usia tua, menimbulkan stres mental yang berkepanjangan, bahwa resiko mengalami depresi. Kecemasan lansia terhadap kematian, mendorong lansia mencoba berbagai cara menghidari kematian dini. Salah satu cara mencegah kematian, dengan melakukan pengobatan-pengobatan secara intensif dengan mengkonsumsi obat-obat untuk mencegah kekambuhan, menghilangkan rasa sakit, dan menghindari komplikasi, hingga menyebabkan ketergantungan pada obat obat tersebut. Perilaku ini telah mengarah pada perilaku adiksi, karena penggunaan obat tanpa pengaturan yang tepat guna dan dikonsumsi terus menerus, tidak dapat dihentikan.

Penyalahgunaan obat yang terjadi pada individu lansia dengan masalah syndrome ketergantungan obat, dapat ditandai dengan kondisi yang disertai dengan ketergantungan fisologis (juga disebut kecanduan) jika terdapat toleransi atau gejala putus zat. Toleransi diindikasikan oleh salah satu dari (a) dosis zat yang dibutuhkan untuk menghasilkan efek yang diinginkan lebih besar atau (b) efek obat menjadi sangat berkurang jika mengonsumsi obat dalam dosis biasa. Orang yang bersangkutan juga menghentikan atau mengurangi jumlah konsumsi zat tersebut (Davison dkk:2014)

Masalah penyalahgunaan obat merupakan masalah yang sangat kompleks, yang memerlukan upaya penanggulangan secara komprehensif dengan melibatkan kerja sama multidispliner, multisektor, dan peran serta masyarakat secara aktif yang dilaksanakan secara berkesinambungan, konsekuen dan konsisten. Ketergantungan obat telah menjadi masalah yang besar, komplex dan sukar di berbagai negara (Maramis:2009).

Ketergantungan obat pada lansia, merupakan kompensasi dari kecemasan panik yang berlebihan dan ketakutan terhadap kematian. Dalam penanganan pada kasus penyalahgunaan obat yang bersumber dari masalah masalah emosional seperti: stres dan kecemasan dapat dilakukan pelepasan ketegangan emosional yang terkait dengan gejala gejala penyalahgunaan obat. Strategi yang melepaskan ketegangan emosional yang terkait dengan gejala. Setelah kenangan emosional terlepas, respon stres berkurang dan tubuh memiliki kesempatan untuk menyembuhkan dirinya sendiri. (Mardihusodo \& Saputra: 2012)

Salah satu terapi yang membantu mengurangi kecemasan pada individu dengan ketergantungan obat adalah terapi Spiritual Emotional Freedom
Technique (SEFT). SEFT termasuk tehnik relaksasi, merupakan salah satu bentuk mind-body therapy dari terapi komplementer dan alternatif keperawatan SEFT merupakan teknik penggabungan dari sistem energy tubuh (energy medicine) dan terapi spiritual dengan menggunakan tapping pada titik-titik tertentu pada tubuh. Terapi SEFT bekerja dengan prinsip yang kurang lebih sama dengan akupuntur dan akupresur. Ketiganya berusaha merangsang titik-titik kunci pada sepanjang 12 jalur energy (energy meridian) tubuh. Bedanya dibandingkan dengan metode akupuntur dan akupresur adalah teknik SEFT menggunakan unsur spiritual, cara yang digunakan lebih aman, lebih mudah, lebih cepat dan lebih sederhana, karena SEFT hanya menggunakan ketukan tingan (tapping). (Zainuddin, 2012)

\section{Sindrom Ketergantungan}

Menurut Pedoman Penggolongan Diagnosis Gangguan Jiwa ke-3 (PPDGJ-3) untuk menegakkan diagnosis ketergantungan zat "mutlak diperlukan bukti adanya penggunaan dan kebutuhan yang terus-menerus". Terdapatnya gejala abstinensi bukan satu-satunya bukti dan juga tidak selalu ada, misalnya pada penghentian pemakaian kokain dan ganja (marihuana). Obat yang diberikan oleh dokter tidak termasuk dalam pengertian ini selama penggunaan obat tersebut berindikasi medis.

Penyalahgunaan dan Ketergantungan adalah istilah klinis/medik-psikiatrikyang menunjukan ciri pemakaian yang bersifat patologik yang perlu di bedakan dengan tingkat pemakaian psikologik-sosial, yang belum bersifat patologik. http//:agus34drajat. files.worpress

Sementara itu Durand dan Barlow (2006) sindrome ketergantungan obat merupakan pola penggunaan substansi psikoaktif yang mengakibatkan distres atau hendaya yang signifikan dalam peran sosial maupun okupasional dan dalam situasi-situasi yang berbahaya.

\section{Kriteria Sindrome Ketergantungan Obat}

Menurut Durand dan Barlow (2006) terdapat kriteria-kriteria dari sindrome ketergantungan obat, yaitu: (a) Adanya keinginan yang kuat atau dorongan yang memaksa (kompulsi) untuk menggunakan zat; (b) Kesulitan dalam mengendalikan perilaku menggunakan zat sejak awal, usaha penghentian atau tingkat penggunaannya; (c) Keadaan putus zat secara fisiologis ketika penghentian penggunaan zat atau pengurangan, terbukti menggunakan zat atau golongan zat yang sejenis dengan tujuan 
untuk menghilangkan atau menghindari terjadinya gejala putus zat; (d) Adanya toleransi, berupa peningkatan dosis zat psikoaktif yang diperlukan guna memperoleh efek yang sama yang biasanya diperoleh dengan dosis lebih rendah (contoh: individu dengan ketergantungan alkohol dan opiat yang secara rutin setiap hari menggunakan zat tersebut secukupnya untuk mengendalikan keinginannya); (e) Secara progresif mengabaikan alternatif menikmati kesenangan karena penggunaan zat psikoaktif lain, meningkatnya jumlah waktu yang diperlukan untuk mendapatkan atau; (f) Menggunakan zat atau pulih dari akibatnya; (g) Terus menggunakan zat meskipun is menyadari adanya akibat yang merugikan kesehatannya

\section{SEFT (Spiritual Emotional Freedom Technique)}

\section{S-EFT (Spiritual Emotional Freedom Technique)} menurut Zainudin (2012) adalah tehnik penyembuhan yang memadukan keampuhan energi psikologi dengan doa dan spiritualitas. Energi psikologis adalah ilmu yang menerapkan berbagai prinsip dan teknik berdasarkan konsep sistem energi tubuh untuk memperbaiki kondisi pikiran, emosi dan perilaku seseorang. Teknik ini pengembangan dari terapi ekletis yang menggabungkan 14 macam teknik terapi termasuk kekuatan spiritual dan doa untuk mengatasi berbagai macam masalah.

SEFT merupakan salah satu terapi komplementer yang dapat digunakan untuk menurunkan tingkat depresi. Keefektifan SEFT terletak pada pengabungan antara Spiritual Power dengan Energy Psychology. Spiritual Power memiliki lima prinsip utama yaitu ikhlas, yakin, syukur, sabar dan khusyu. Energy Psychology merupakan seperangkat prinsip dan teknik memanfaatkan system energy tubuh untuk memperbaiki kondisi pikiran, emosi dan perilaku (Freinstein dalam Zainudin, 2012). Ketidakseimbangan kimia dan gangguan energi dalam tubuh manusia dapat menyebabkan gangguan emosi, termasuk depresi. Intervensi SEFT pada sistim energi tubuh inilah yang dapat mengubah kondisi kimia di dalam otak (neurotransmitter) yang selanjutnya dapat mengubah kondisi emosi seseorang termasuk kondisi depresi. Selain itu SEFT efektif, mudah, cepat, murah, efeknya dapat permanen, tidak terdapat efek samping, bersifat universal, memberdayakan individu (tidak tergantung pada pemberi terapi), dapat dijelaskan secara ilmiah (Zainudin: 2012)

\section{METODE}

Penelitian ini merupakan penelitian yang menggunakan pendekatan kualitatif dengan metode studi kasus. Studi kasus menurut Poerwandari (2012) didefinisikan fenomena khusus yang hadir dalam suatu konteks yang terbatasi (bounded context), meski batas-batas antara fenomena dan konteks tidak sepenuhnya jelas. Tipe studi kasus pada penelitian ini, studi kasus instrumental. Studi kasus instrumental merupakan penelitian pada suatu kasus unik tertentu dilakukan untuk memahami isu dengan lebih baik, juga untuk mengembangkan, memperluas teori.

Penelitian ini mengambil sampel seorang lansia berusia 63 tahun yang memiliki perilaku adiksi pada obat obatan berjenis antibiotik yang dapat menghilangkan rasa nyeri, analgesik yang dapat menghilangkan rasa sakit pada keluhan keluhan fisik yang dirasakan subjek, antihistamin yang memiliki efek samping mengantuk. Penetitian ini dilakukan selama 36 hari, dan selama 21 hari intervensi SEFT diterapkan. Setiap hari subjek melakukan SEFT selama 5-10 menit setelah selesai sholat 5 waktu dan ketika subjek merasakan emosi negatif muncul. Lokasi penelitian ini dilaksanakan di desa Kejapanan, kecamatan Gempol, Kabupaten Pasuruan, Jawa Timur.

Untuk mendapatkan data pada lansia dengan syndrome ketergantungan obat, data dikumpulkan dengan melakukan teknik wawancara mendalam dan observasi partisipan bertujuan untuk mengetahui faktor-faktor penyebab ketergantungan obat. Sedangkan untuk mengukur tingkat efektifitas SEFT terhadap tingkat kecemasan dan stres pada lansia dengan syndrome ketergantungan obat, dilakukan dengan skala Depression, Anxiety and Stress Scale 21 Items (DASS21) sebelum dan sesudan intervensi SEFT dilakukan.

\section{HASIL DAN PEMBAHASAN}

Kemampuan coping stres subjek menunjukkan tingkat yang sangat rendah. Berdasarkan hasil wawancara, subjek individu yang mudah berpikir buruk dan negatif yang menyebabkan subjek paranoid ketika mengalami masalah. Subjek lebih memilih untuk menghindari masalah dan tidak menyelesaikan masalah sampai tuntas. Permasalahan yang tidak terselesaikan yang terus tersimpan dalam ingatan bawah sadar subjek menyebabkan gangguan psikologis seperti: mudah marah-marah, mudah merasa cemas, kecenderungan paranoid, khawatir, pikiran yang negatif terus, serta merasa tidak 
tenang. Gangguan-gangguan psikologis atau sakit fisik terjadi karena terdapat sejumlah hambatan energi negatif pada pembuluh meridian tempat mengalirnya chi. Ketika subjek mengalami gangguan psikologis tersebut, maka telah terjadi ketidak seimbangan berupa adanya hambatan berupa energi negatif pada sistem meridiannya.

Kondisi yang dialami subjek terjadi sebagai akibat ketidakmampuannya untuk memaknai persoalan yang dihadapinya secara positif. Ketidakmampuan subjek memaknai setiap persoalan menyebabkan terganggunya sistem tubuh sehingga subjek sering mengalami sakit fisik, seperti: sakit kepala, jantung berdebar, tidak tenang, demam dan mudah sakit influensa. Dampak terganggunya sistem tubuh ini menyebabkan subjek sering merasakan emosi negatif setiap hari.

Ketika mengalami persoalan atau permasalahan, subjek tidak mampu memaknai persoalan yang dihadapi secara positif. Subjek tidak dapat mencapai kebahagiaan dan memaknai setiap peristiwa secara positif dari sudut pandang spiritualitas, namun subjek mengatasi setiap masalahnya dengan mengalihkan fokus pada pengobatan sakit fisik yang diderita. Sehingga subjek selalu mengkonsumsi obat setiap hari secara teratur meskipun terkadang gejala gejala sakit fisik tidak muncul. Hal ini dilakukan dengan tujuan untuk pencegahan sebelum terasa sakit muncul, dan sebagai bentuk coping stress dari masalah masalah subjek. Selain itu, pengalaman masa lalu ketika subjek sakit parah yang tak kunjung sembuh menyebabkan subjek bertindak tanpa berfikir positif atas tindakannya. Penggunaan obat-obatan berjenis antibiotik yang dapat menghilangkan rasa nyeri, analgesik yang dapat menghilangkan rasa sakit pada keluhan keluhan fisik yang dirasakan subjek, antihistamin yang memiliki efek samping mengantuk, sering di lakukan tanpa pengawasan dokter.

Ketergantungan obat yang di alami oleh subjek merupakan kondisi yang disebabkan oleh gagalnya subjek melakukan managemen stres pada tahap resisten sehingga menyebabkan kondisi kesehatan fisik subyek berpengaruh. Pengalihan masalah masalah subjek untuk pada penggunaan obat-obatan pencegah dan penghilang penyakit fisik, pada dasarnya bersumber dari permasalah psikologis subjek. Hasil pengukuran untuk menilai efektifitas SEFT sebelum dan sesudah dilakukan intervensi pada subjek menunjukkan:
Depression, Anxiety and Stress Scale - 21 Items (DASS21)

\begin{tabular}{lllll}
\hline & Pre test & \multicolumn{2}{l}{ Post } & test \\
\hline Kategori & Skor & Interpretasi & Skor & Interpretasi \\
\hline Depresi & 6 & Normal & 4 & Normal \\
\hline Kecemasan & 14 & Sedang & 10 & Sedang \\
\hline Stres & 19 & Tinggi & 9 & sedang \\
\hline
\end{tabular}

Hasil pre test dan post test menunjukkan tingkat kecemasan subjek pada kategori sedang. Pasca intervensi belum menunjukkan penurunan tingkat kecemasan, namun skor post-test menurun 4 poin, dari skor pre test 14 berkurang menjadi skor 10 point. Tingkat stress dari tinggi menjadi sedang, skor menurun 10 point. Pada alat ukur DASS-21 norma berat-ringan gangguan dilihat dari paling rendah ke tinggi yaitu: stres, kecemasan hingga depresi. Hasil pengukuran tersebut dapat diartikan bahwa dengan intervensi yang diberikan tingkat stres dan kecemasan mulai menurun. Dari hasil derajat gangguan yang sebelumnya cemas menjadi lebih ringan yaitu pada kategori stres saja.

Efektifitas SEFT (Spiritual Emotional Freedom Technique) pada penanganan kasus lansia yang mengalami syndrome ketergantungan obat, yangmana penyebab perilaku adiksi subjek karena adanya masalah psikologis seperti: kecemasan dan stres psikologi menunjukkan sangat efektif dan memiliki dampak perubahan pada aspek emosional subjek. Melalui SEFT, subjek belajar melakukan managemen stres yang benar ketika memiliki masalah di rumah dan tidak mengalihkan pada penggunaan obat-obatan yang berlebihan. SEFT sangat tepat di berikan pada subjek yang mudah sekali terpicu mengalami masalah emosional seperti: perasaan gelisah tanpa sebab, mudah berpikir buruk dan negatif yang menyebabkan subjek paranoid ketika mengalami masalah, mudah marah-marah, mudah merasa cemas, kecenderungan paranoid, khawatir, pikiran yang negatif terus, serta merasa tidak tenang.

Menurut Zainudin (2012) terapi SEFT adalah terapi dengan menggunakan gerakan sederhana yang dilakukan untuk membantu menyelesaikan masalah permasalahan sakit fisik maupun psikis, meningkatkan kinerja dan prestasi, meraih kedamaian dan prestasi serta kebermaknaan hidup. Lebih lanjut lagi menurut Zainudin, SEFT adalah tehnik penyembuhan yang memadukan keampuhan energi psikologi dengan doa dan spiritualitas. Energi psikologis adalah ilmu yang menerapkan berbagai prinsip dan teknik berdasarkan konsep sistem energi 
tubuh untuk memperbaiki kondisi pikiran, emosi dan perilaku seseorang.

Pada setiap ketukan-ketukan yang dilakukan oleh subjek dengan disertai energi yang memusatkan pada aktivitas doa dan keyakinan diri atas kekuatan spiritualitas sebagai mahkluk yang bertuhan, subjek belajar untuk menerima, sabar, ikhlas dan pasrah atas kondisi yang dialami subjek. Setiap tahapantahapan dalam SEFT mengubah kondisi kimia di dalam otak (neurotransmitter) yang selanjutnya dapat mengubah kondisi emosi seseorang termasuk kondisi kecemasan dan stres yang dialami subjek.

Menurut Zainuddin (2012), setiap ketukan pada SEFT, sebagai berikut: (a) The Set-Up, bertujuan untuk memberikan kepastian agar aliran tubuh yang dirasakan dengan tepat. Tujuan yang lebih penting adalah menetralisasi psychological reversal atau perlawanan psikologis. The set up menggunakan kata-kata sugesti spiritual yang pada akhirnya dapat memeberikan keyakinan atau kepasrahan untuk dapat mengelola kegalauan emosi yang hadir termasuk kecemasan dan marah, (b) The Tune-in; dapat dilakukan dengan cara memikirkan sesuatu atau peristiwa spesifik tertentu yang dapat membangkitkan emosi negatif yang ingin dihilangkan atau merasakan sakit fisik yang sedang dialami. Cara ini dapat menetralisasi emosi negatif atau sakit fisik yang sedang dirasakan. Saat melakukan tune in individu harus mengulang-ulang kata pengingat yang mewakili emosi negatif yang dirasakan, (c) The Tapping adalah mengetuk ringan dengan dua ujung jari pada titik tertentu di tubuh kita lebih kurang 7 kali ketukan terus tune in. Titik titik ini adalah ujung jari dari the mayor energy meridian yang pada dasarnya apabila diketuk beberapa kali akan berdampak pada ternetralisasinya gangguan emosi atau rasa sakit yang dirasakan.

Pengaruh SEFT juga di rasakan memberi perubahan pada tekanan darah subjek, yang ditunjukkan dengan penurunan tingkat detak jantung, berkurangnya rasa sakit kepala (pusing), tubuh tidak mudah lelah yang diikuti pola tidur yang lebih awal jam tidur subjek. Hal ini menunjukkan tingkat stres subjek menurun setelah melakukan SEFT pada saat setelah ibadah sholat. SEFT memberikan efek relaksasi pada tubuh subjek. Efek relaksasi ini dapat menenangan emosi, dan perasaan subjek lebih terasa nyaman. Menurut Halm (2009), terapi spiritual berpengaruh terhadap aktivitas sistem saraf simpatis, dampak dari relaksasi tersebut pernapasan menjadi lebih lambat iramanya, nadi lambat, tekanan darah turun, menurunkan konsumsi oksigen otot jantung dan ketegangan otot. Respons relaksasi juga berpengaruh pada kondisi mental dan menurunkan ketegangan otot sehingga menimbulkan suasana yang nyaman, dapat menurunkan stres juga memengaruhi interaksi dari psychoneuroendocrine. Respons relaksasi dapat memperbaiki prognosis pada penyakit jantung koroner dan meningkatkan fungsi kekebalan tubuh, relaksasi dapat mengurangi intervensi sistem saraf simpatis dan meningkatkan aktivitas sistem saraf parasimpatis (Jacobs: 2001)

Sedangkan, hasil penelitian yang dilakukan Rifacky (2014), pada responden hipertensi kelompok intervensi yang diberikan perlakuan terapi SEFT mengalami perubahan penurunan tekanan darah sedangkan pada kelompok kontrol atau kelompok yang tidak diberikan perlakuan terapi teknik SEFT mengalami penurunan tekanan darah yang tidak bermakna. Hal tersebut salah satunya disebabkan oleh pemberian terapi SEFT selama satu kali 15 menit selama satu hari dapat membantu menurunkan tekanan darah karena bersifat relaksasi dan menekan produksi hormon stres seperti epinefrin dan kortisol, yang akan berefek pada penurunan kerja jantung dan curah jantung.

Penelitian lain menunjukkan, masalah emosi maupun masalah fisik yang dialami oleh seseorang misalnya dismenorea maka tingkat nyeri yang dirasakan akan berkurang, bahkan akan hilang dalam waktu yang singkat. Hal ini dikarenakan SEFT lebih menekankan pada unsur spiritualitas (doa) dan sistem energi tubuh dengan menggunakan metode tapping pada beberapa titik tertentu pada tubuh. Selain sistem energi tubuh terdapat pula metode relaksasi dengan melibatkan faktor keyakinan pasien yang diyakini dapat mengurangi nyeri yang dirasakan (Zakiyyah:2013).

SEFT menunjukkan dapat mengurangi tingkat kecemasan dan stres pada subjek, hal ini ditunjukkan dengan mulai berkurangnya gejala-gejala stres yang di alami subjek. Subjek telah mampu mempersepsi sumber-sumber stres psikologis dan merespon dengan melakukan mekanisme coping stres dengan SEFT. Ketika respon positif terhadap stres dapat dikelola dengan baik, maka respon tubuh terhadap stres akan bersifat positif. Oleh karena itu, keluhankeluhan fisik subjek berangsur-angsur mulai berkurang dan menghilang. Berkurangnya keluhankeluhan fisik di-ikuti mulai berkurangnya subjek mengkonsumsi obat-obatan sebagai penghilang rasa sakit dan nyeri. Keluhan-keluhan tidak dirasakan subjek ketika beraktifitas sehari-hari. Kondisi ini mengurangi perilaku ketergantungan obat subjek 
secara berangsur-angsur, dan kesehatan fisik subjek tidak menunjukkan ada keluhan-keluhan fisik, maka perilaku mengkonsumsi obat sebagai mekanisme coping stres subjek dapat dihindari dan dialihkan pada aktivitas SEFT.

Suatu rangsangan atau stresor akan mengaktifkan aksis Hiphotalamic-Pituitary Adrenal (HPA), yang dicerminkan oleh pelepasan Cortocotropin-Releasing Hormon (CRH) dan vasopresin (AVP) oleh nukleus praventrikular dari hipotalamus, kemudian akan merangsang produksi dari Andrenocorticotropic Hormon (ACTH) oleh kelenjar pituatari anterior. ACTH ini akan merangsang sintesis dari glukokortikoid di kelenjar korteks adrenal pengaturan aksis HPA yang seimbang sangat penting untuk ketahanan hidup sel dan kesehatan (Herman dalam Putra: 2011).

Persepsi stres subjek mampu dirubah otak dan sistem perifer yang menyebabkan subjek mampu melakukan mekanisme coping atau adaptasi terhadap stressor tersebut dengan SEFT. Perubahan persepsi positif berpengaruh pada meningkatnya ketahanan tubuh dan kesehatan fisik subjek. Subjek mampu mengelola sumber sumber stres dengan intensif melakukan SEFT sebagai strategi managemen coping stress yang terfokus pada masalah. Sehingga subjek dapat mengurangi ketergantungan obat karena tidak lagi mengalami keluhan-keluhan fisik dan psikologis.

\section{KESIMPULAN}

Berdasarkan hasil studi kasus diatas dapat disimpulkan bahwa intervensi SEFT (Spiritual

\section{DAFTAR ISI}

Davison, Gerald., Neale., John., \& Kring., Ann. 2014. Psikologi Abnormal. Edisi ke 9. Depok: PT Rajagrafindo Persada.

Durand, V. Mark \& David H.Barlow, 2006. Psikologi Abnormal. Edisi ke empat. 2006. Yogjakarta: Pustaka Pelajar.

Halm, A.Margo. (2009), Relaxation: A self-care healing modality reduces harmful effects of anxiety. The American Association of Critical-Care Nurses $A A C N, 18,169172$.http://citeseerx. ist. psu.edu/viewdoc/download?doi=10.1.1.607.184 \&rep=rep1\&type=pdf

Rofacky, H. Fajri. 2014. Pengaruh Terapi Spiritual Emotional Freedom Technique (Seft) terhadap Tekanan Darah pada Penderita Hipertensi di Wilayah Kerja Puskesmas Bergas Kecamatan Bergas Kabupaten
Emotional Freedom Technique) dapat mengurangi perilaku ketergantungan obat, yang dikarenakan adanya kecemasan dan stres pada lansia. SEFT menunjukkan efektif mengurangi keluhan-keluhan fisik dan psikologis secara bermakna. Hasil pre test dan post test menunjukkan tingkat stres menurun, skor post-test menurun 4 poin, dari skor pre test 14 berkurang menjadi skor 10 point. Tingkat stress dari tinggi menjadi sedang, skor menurun 10 point, dari 19 menjadi 9. Sedangkan kecemasan Pada alat ukur DASS-21 norma berat-ringan gangguan dilihat dari paling rendah ke tinggi yaitu: stres, kecemasan hingga depresi. Hasil pengukuran tersebut dapat diartikan bahwa dengan intervensi yang diberikan tingkat stres dan kecemasan mulai menurun. Dari hasil derajat gangguan yang sebelumnya cemas menjadi lebih ringan yaitu pada kategori stres saja.

Perubahan persepsi positif terhadap sumbersumber stress berpengaruh pada meningkatnya ketahanan tubuh dan kesehatan fisik subjek. Subjek mampu mengelola sumber sumber stres dengan intensif melakukan SEFT sebagai strategi managemen coping stress yang terfokus pada masalah. Berkurangnya masalah fisik dan psikologis, diikuti berkurangnya konsumsi obat-obatan antibiotik, analgesik dan antihistamin. Dengan demikian SEFT menunjukkan ada pengaruh yang efektif menyembuhkan lansia yang mengalami syndrome ketergantungan obat.

Semarang. Jurnal Program Studi keperawatan STIKES Ngudi Waluyo Ungaran. www. perpusnwu. web.id

Jacobs, D,Gregg. (2001). Clinical applications of the relaxation responsse and mind-body interventions. The Journal Of Altrenative and Complementary Medicine, 3, 93-101

http://gemini.utb.edu/nurs3304_84/ Assignment_7_Mind\%20Body\%20Clinical\%20 Application_5921199.pdf

Papalia, Diane., Olds, S. Wendkos., \& Feldman, R. Duskin. (2009). Human Development. Edisi 10. Jilid 2. Jakarta: Salemba Humanika.

Poerwandari, E. Kristi. 2012. Pendekatan Kualitatif untuk Penelitian Perilaku Manusia. Depok: LPSP3 Universitas Indonesia. 
Putra, S.Taat. 2011. Psikoneuroimunologi Kedokteran. Edisi 2. Surabaya: Airlangga University Press

Safari, T. \& Saputra, N.E., 2009. Managemen Emosi: Sebuah Pandangan Cerdas Bagaimana Mengelola Emosi Positif Dalam Hidup Anda. Jakarta: PT Bumi Aksara.
Zainuddin, A.F., 2012. Spiritual emotional fredom technique (SEFT) for Healing, Succes, Happiness, Greatness. Jakarta: Afzan Publishing

Zakiyyah. Muthmainnah. 2013. Pengaruh Terapi Spiritual Emosional Freedom Technique (Seft) Terhadap Penanganan Nyeri Dismenorea. Skripsi Prodi Akademi Kebidanan, Hafshawaty Zainul Hasan, Genggong Probolinggo 